Проблемы старения и долголетия. Тезисы V конгресса геронтологов и гериатров Украины, Киев 12-14 октября 2010 г. 2010. № 3. С. 221.

2. Артьомов О.В., Бурячківський Е.С. Тривалість життя тканинної системи в аспекті математичного закону старіння. Досягнення біологіi та медицини. 2017. № 1(29). С. 10-13.

DOI https://doi.org/10.30525/978-9934-26-038-4-42

\title{
APPLICATION FEATURES OF MODERN ADHESIVE SYSTEMS AS A DENTAL LINER
}

\author{
Vakhovskyi V. V. \\ Assistant at the Therapeutic Dentistry Department \\ National Pirogov Memorial Medical University
}

Aleksyeyenko N. S.

Assistant at the Therapeutic Dentistry Department

National Pirogov Memorial Medical University

Pylypiuk O. Y.

Ph. D. in Medicine,

Assistant at the Therapeutic Dentistry Department

National Pirogov Memorial Medical University

Filimonova S. O.

Assistant at the Department of Therapeutical Stomatology

National Pirogov Memorial Medical University

Androshchuk O. V.

Ph. D. in Medicine,

Associate Professor at the Department of Pathological Physiology

National Pirogov Memorial Medical University

Vinnytsya, Ukraine

To our minds, the topic of this issue is being significant and actual in all the times. Mechanisms of filling materials retention to hard tooth tissues remain one of the most important problems in modern dental practice. However, with the advent of composite materials and the first adhesive systems, doctors decided that they had found the right way to solve the problem. 
However, even with the advent of modern IV, V, VI and VII systems, it is still crucial to adhere to the correct protocol for the use and selection of the adhesive [1, p. 9].

Adhesive systems are a set of complex substances - the etching component (if present), a primer and a bond that provide a micromechanical connection to the hard tissues of the tooth of various dental materials. At the present stage of the development of dentistry, high-tech materials are used, through which the aesthetic, anatomical and functional parameters of the tooth can be restored [2, p. 311]

In addition to the strength of bonding the filling material to the tissues of the tooth, it is also important to eliminate the toxic effect of the filling material on the pulp. For a long time, bioinert fillers (glass ionomer and polycarboxylate cements) have been used to isolate the pulp from filling materials with a potential negative impact on the pulp. But they also separated the composite material from the adhesive layer, and as a consequence, the adhesive strength decreased. This was one of the causes of many complications [3, p. 58].

Dentin with pulp form a single functional system - the dentin-pulp complex. It was proved that the best protection of the pulp from the stimuli is its own dentin, and the greater the thickness of the dentin, the better: at a thickness of «dentinal bridge» in $0.5 \mathrm{~mm}$ pathological effect on the pulp is reduced by $75 \%$, and at a thickness of $1 \mathrm{~mm}-90 \%$. Accordingly, the best dental liner is sclerosed and replacement dentin (the most mineral types of dentin) $[4$, p. 4-10].

If there is still a deep carious process and the thickness of the dentin is very small, then the first task is to create a seal for the pulp [5, p.125]. Dentine tubules are the direct pathway of microorganisms and toxic components of the filling material to the pulp. Using the adhesive protocol reduces the contamination by microorganisms (by etching), and reliably seals the dentinal tubules (by polymerization), and of course creates a large adhesion force of the filling material to the tooth tissues (about $20 \mathrm{MPa}$ ), which is the largest among all filling materials [6, p. 50].

Therefore, through the application of modern adhesive systems, dentists have found the right path to maximum adhesion strength, but are not sure whether they are sufficient to reliably isolate the pulp from adverse effects and prevent complications. Nevertheless, recent studies have shown that modern adhesive systems are not only high-quality «dental liner», but also have reparative properties, and in some cases can be used to directly cover the pulp. Greatest complications after filling with composite materials, without the use of dental liner, arise only because of ignorance or failure to observe the protocol of using a particular generation of the adhesive system [7, p. 298]. 


\title{
References:
}

1. Ганс Йорг Штеле. // Стоматология. - 2004. - № 1. - С. 9-12.

2. Eick, J. D. Current concepts on to adhesion dentin / J. D. Eick, D. H. Pashley // Crit. Rev. Oral. Biol. Med. 1997. Vol. 8. № 3. P. 310-315.

3. Луцкая И.К. Практическая стоматология. - Мн., 2001. - С. 58-59.

4. Храмченко С.Н. Сравнительная характеристика современных адгезивных систем: Автореф. дис. ... к.м.н. - Минск, 2009.

5. Accorinte M, Loguercio A, Reis A, de Souza Costa C. // Clinical Oral Investigations. 2008. № 12. P. 121-127.

6. Microtensile bond strength of a total-etch 3-step, total-etch 2-step, self-etch 2-step, and a self-etch 1-step dentin bonding system through 15-month water storage / S. R. Armstrong [at al.] // J. Adhes Dent. 2003. № 5. P. 46-55.

7. Silva G, Lanza L, Lopes-Júnior N, Moreira A, Alves J. // Operative Dentistry. 2006. № 31(3). P. 297-307.

DOI https://doi.org/10.30525/978-9934-26-038-4-43

\section{ЦИФРОВА МЕДИЦИНА - ІННОВАЦІЯ МАЙБУТНЬОГО}

\author{
Дорощук С. М. \\ асистент кафедри описової та клінічної анатомії \\ Національний медичний університет імені О. О. Богомольия
}

\author{
Гайдай О. С. \\ кандидат медичних наук, \\ доиент кафедри описової та клінічної анатомії \\ Наиіональний медичний університет імені О. О. Богомольия
}

\author{
Маліновська Н. М. \\ асистент кафедри описової та клінічної анатомії \\ Національний медичний університет імені О. О. Богомольия \\ м. Київ, Украӥна
}

Розвиток медицини в XXI столітті стикається з певними проблемами, серед яких варто виділити: зростаючий попит на управління хронічними захворюваннями та відповідне збільшення витрат на охорону здоров'я. Розвиток цифрової охорони здоров'я відбувався тільки у 2010-х роках, і таким чином вона все ще перебуває на етапі формування, як і ті виклики, що виникають разом з нею. 